\title{
What Makes an Effective English Language Teacher? The Life Histories of 13 Mexican University Students
}

\author{
Nicholas Bremner ${ }^{1}$ \\ ${ }^{1}$ School of Education, Bath Spa University, Bath, United Kingdom \\ Correspondence: Dr Nicholas Bremner, NE.106, School of Education, Bath Spa University, Newton St Loe, Bath, \\ BA2 9BN, United Kingdom.
}

Received: September 19, 2019

Accepted: December 20, 2019

Online Published: December 30, 2019

doi: 10.5539/elt.v13n1p163

URL: https://doi.org/10.5539/elt.v13n1p163

\begin{abstract}
This study examined the educational life histories of 13 students at a Mexican university in order to gather their perspectives of effective language teaching. Most previous studies on students' perspectives of language teaching have used quantitative and deductive methods, whereas this study employed qualitative and inductive methods. The main methodological approach was the 'life history' approach, and the specific methods were two extended interviews and an innovative 'timeline' activity. In total, 77 examples of effective (and ineffective) teachers emerged from the 13 students' life histories. The study revealed three major findings. Firstly, teachers' language knowledge and proficiency were not mentioned as important characteristics of effective language teaching, although several students did make reference to teachers' command of language when it was perceived to be missing. Secondly, students generally favoured more 'modern' approaches (engaging, active, real-life skills, immersion in the target language), as opposed to more 'conservative' approaches (unappealing, passive, overly theoretical, lack of immersion in the target language). Thirdly, students emphasised the importance of a positive student-teacher relationship, and greatly appreciated the teacher being there to provide them with personalised attention. Notably, the students tended not to value autonomous learning, preferring teachers to be close to them to help them with their problems in class. Two main implications for practice were suggested. Firstly, a general consensus has been reached regarding several key characteristics of effective language teaching, strengthening the argument that these characteristics should be listened to, and acted upon, by teachers and educational decision-makers. Secondly, the study makes a strong case for future research to utilise more qualitative, inductive methods when investigating students' perspectives.
\end{abstract}

Keywords: effective teaching, good teaching, English language teaching, student perspectives, learner perspectives, Mexico, life history, timeline, qualitative methods, inductive methods

\section{Introduction}

What makes a 'good' or 'effective' teacher? What 'works' in the classroom? What teaching approaches are most successful in achieving language learning? These are the types of questions that should, and do, permeate the decision-making of all committed language teachers.

Traditionally, standards of teaching 'effectiveness' have often been imposed from the outside, through an 'etic' perspective. However, another option, which has gained increased traction in recent decades, is the 'emic' perspective, which aims to understand the views of those directly involved in the activity itself. In the case of language teaching, the main actors are, of course, teachers and students. However, whilst considerable emphasis has been placed on teachers' views of teaching effectiveness, often studied through the lens of teacher beliefs or cognitions (Borg, 2006), student perspectives of teacher effectiveness are still relatively underrepresented, especially in the area of language learning (Barnes \& Lock, 2010; Han, 2017; Richter \& Lara Herrera, 2017). Moreover, the vast majority of studies that have investigated students' perspectives have employed quantitative and/or deductive methods, and have asked participants to define 'effective' teaching in rather abstract terms.

This article reports on the findings of an inductive qualitative study that used life history research, and specifically, the timeline methodology, to explore the concrete life experiences of 13 students at a Mexican university. The students made reference to a total of 77 different English language teachers, and reported a wide range of positive and negative experiences. The findings indicated that teachers' English knowledge and proficiency were not considered as important as teachers' personalities and teaching approaches. Students 
generally favoured more 'modern', active, student-centred classes, and placed a great deal of emphasis on positive teacher-student relationships. Finally, students much preferred teachers who were available to help them in class, as opposed to those who encouraged student autonomy.

Two main implications for policy and practice can be drawn from the study. Firstly, given that several key themes emerge consistently across the literature, this reiterates the need for policy and practice to take students' perspectives into account. Secondly, given that the study showed that students often answer differently in their own words as opposed to responding to pre-established categories, this suggests that future approaches to gathering students' perspectives must consider more qualitative, inductive methods of data collection.

\section{Literature Review}

An early study on student perspectives of effective language teaching was that of Brosh (1996), who gathered the perspectives of 200 foreign language teachers and 406 high school students in Israel. With a few exceptions, Brosh found that there was a great deal of similarity between teacher and students' views, and summarised that the main characteristics of an effective teacher were:

- Knowledge and command of the target language;

- Ability to organize, explain, and clarify;

- Ability to arouse and sustain interest and motivation among students;

- Fairness to students; and

- Availability to students.

(Adapted from Brosh, 1996: 133)

Since Brosh's study, the vast majority of work on students' perceptions of effective teaching have employed quantitative methodologies (Al-Mahrooqi, Denman, Al-Siyabi, \& Al-Maamari, 2015; Alimorad \& Tajgozari, 2016; Arikan, Taşer, \& Saraç-Süser, 2008; Babai Shishavan \& Sadeghi, 2009; Barnes \& Lock, 2013; Brown, 2009; Çelik, Arikan, \& Caner, 2013; Chen, Y-J, Lin, 2009; Han, 2017; Kourieos \& Evripidou, 2013; Meksophawannagul, 2015; Park \& Lee, 2006). The findings of these studies demonstrate several similarities, both to each other and to early studies like Brosh (1996). Firstly, there is general agreement that language knowledge and proficiency are vital characteristics of effective teaching, but that being a native speaker of the language is not crucial. Secondly, the teachers' personality and their ability to maintain positive relationships with students are consistently highlighted as extremely important. Thirdly, students tend to favour more 'modern', active, student-centred approaches as opposed to more 'conservative', passive, teacher-centred approaches (the terms 'modern' and 'conservative' are used in this study, as in Richter and Lara, 2017).

One study that found contrasting results was that of Brown (2009), who administered a survey to 1600 students of nine different foreign languages at a university in the United States. Brown found that the students valued communicative approaches significantly less than the teachers, and expressed that they would like more, if not total, emphasis on grammar-based approaches. It must be recognised that Brown's study took place in one specific university context, and there will inevitably be differences in different countries and cultures (Schultz, 2001). However, the vast majority of studies carried out since then have not corroborated Brown's work; on the contrary, they have found that students prefer more 'modern', student-centred approaches (Alimorad \& Tajgozari, 2016; Barnes \& Lock, 2013; Kourieos \& Evripidou, 2013).

A key limitation of the aforementioned studies is that they were all deductive in nature. Through closed questionnaires, most created pre-established characteristics for participants to rate, with little or no scope to offer their own suggestions. Indeed, whilst a handful of the quantitative studies included more qualitative and/or inductive methods, these were often merely an 'add-on' at the end of the questionnaire. For example, in their study with Iranian students, Babai Shishavan and Sadeghi (2009) included a qualitative, 'open' section in their questionnaire. In the qualitative component, the students highlighted several characteristics that had not been included in the questionnaire, such as patience, flexibility, and adapting to students' needs. The fact that these seemingly important characteristics of effective teaching were not included in the questionnaire may lead us to question why qualitative, inductive methods were not used to inform the design of the questionnaire itself.

Relatively few studies on language teacher effectiveness have been completely qualitative in nature. A notable exception was the study of Barnes and Lock (2010), who asked 38 students at a women's university in South Korea to write, in their own words, what made an effective English language teacher. All responses were coded, and emerging attributes were categorised into five groups based on the framework of Faranda and Clarke (2004). As shown below, attributes related to 'rapport' and 'delivery' were by far the most mentioned in the study: 
- Rapport - 37\% (e.g. is friendly, develops interpersonal relationships, shares personal life experiences, cares about students, is patient);

- Delivery - 36\% (e.g. is enthusiastic, gives clear explanations, uses good examples, uses a variety of methods, uses the L1 selectively, uses group work, encourages participation);

- Fairness - 10\% (e.g. treats all students impartially, prepares students well for examinations, provides clear grading guidelines);

- Organisation and preparation - 9\% (e.g. is well-prepared, provides a syllabus, tells students lesson objectives);

- Knowledge and credibility - 7\% (e.g. is well-qualified, has good knowledge of grammar and vocabulary).

(Adapted from Barnes \& Lock, 2010: 143-148)

In relation to the 'delivery' group, Barnes and Lock highlighted that most students tended to value a more 'modern' approach to language teaching, despite Korea typically having a very conservative educational culture. Moreover, it was interesting to note that 'knowledge and credibility' were not mentioned anywhere near as often as in the previously cited quantitative studies. In other words, when students were asked specifically if they thought language knowledge was important, they generally answered that it was (as in, for example, Al-Mahrooqi et al., 2015; Han, 2017; Meksophawannagul, 2015). However, when they were simply asked to describe an effective teacher in their own words, language knowledge was not mentioned as frequently.

A more recent qualitative study was carried out by Oskouei, Dabaghi, \& Nejad Ansari (2018), who carried out semi-structured interviews with 22 students at an Iranian university. The main finding emerging from the study was that the students again favoured more 'modern', student-centred approaches, thus supporting the findings of most previous research. However, it is worth noting that this qualitative study was much more deductive than the work of Barnes and Lock (2010), as the researchers prepared specific questions for students to answer in detail. One example of this was that the researchers asked students whether 'teacher appearance' was important, and most answered that they felt it was. However, it remains to be seen whether the students would have even mentioned teacher appearance if they had been asked to describe an 'effective' language teacher in their own words.

A final study worth mentioning is the work of Richter and Lara Herrera (2017). This research was especially pertinent to the present study; firstly, because it was the only relevant study to include participants from Mexico, but also because it employed a rather innovative 'repertory grid' method. The repertory grid technique invited students (59 from Mexico and 57 from South-East Asia) to choose their own 'constructs' and rate the extent to which an 'effective' language teacher would score on their scales (for example, students could rate 'punctuality' from 'extremely punctual' to 'not punctual at all'). The constructs were then coded qualitatively into key themes, and the relative prevalence of these themes was analysed statistically. The main findings were, firstly, that students felt that 'personality traits' and 'rapport with students' were extremely important; and secondly, that like previous studies, there was a clear focus towards more 'modern' teaching approaches.

The present study develops the work of authors such as Barnes and Lock (2010) and Richter and Lara Herrera (2017). It is an inductive, emic study in which the students themselves were able to express their own views of effective language teaching. Moreover, whilst most previous studies have asked participants to describe 'effective' teaching in rather general, abstract terms, this study used the life history approach to allow students to reflect upon several concrete experiences with real teachers. Indeed, although there were only 13 participants in the study, they made reference to a total of 77 different teachers, meaning that a wide range of characteristics of effective (and ineffective) teaching emerged from the data. The methods of the study are summarised in the following section.

\section{Methods}

\subsection{Context and Participants}

The present study represents the extension of a larger research project which explored the educational life histories of five experienced English language teachers at a Mexican university (Bremner, 2017). The research took place at the 'University of San Martín' (USM), a public university located in a state capital in Mexico. The participants were 13 undergraduate students at the USM. The sampling strategy of the study was purposive, as it aimed to gather the experiences of those who had studied English for several years in the Mexican context. The participants were recruited from a pool of 33 students who had taken part in student focus groups in Bremner 
(2017). At the end of the focus groups, the aims of the new study were explained and the students were invited to take part. It was made clear to participants that there was no pressure to be involved; however, over a third of students from the focus groups (13 in total) volunteered to take part.

The participants were aged between 18 and 21, with the exception of Alfonso, who was considered a 'mature' student at 28. The participants were studying a range of different degrees and had a range of different levels (see Table 1 below for details). It is worth noting that all real names, including the name of the institution, have been replaced by pseudonyms, and that each of the 77 teachers mentioned in the study were assigned numbers (Teacher 1, Teacher 2, etc.).

Table 1. Summary of key information about the participants

\begin{tabular}{lllllll}
\hline $\begin{array}{l}\text { Name } \\
\text { (pseudonym) }\end{array}$ & Sex & Age & Degree & $\begin{array}{l}\text { Year of } \\
\text { uni study }\end{array}$ & $\begin{array}{l}\text { Started learning } \\
\text { English in }\end{array}$ & $\begin{array}{l}\text { Appropriate level } \\
\text { (CEFR) }\end{array}$ \\
\hline Anabel & $\mathrm{F}$ & 18 & Special Needs & $1^{\text {st }}$ & Secondary & Intermediate (B1) \\
Alfonso & $\mathrm{M}$ & 28 & Design & $3^{\text {rd }}$ & Secondary & Elementary (A2) \\
Beatriz & $\mathrm{F}$ & 21 & Tourism & $4^{\text {th }}$ & Pre-school & Upper intermediate (B2) \\
Camila & $\mathrm{F}$ & 18 & Social Work & $1^{\text {st }}$ & Secondary & Elementary (A2) \\
Dolores & $\mathrm{F}$ & 19 & Education & $2^{\text {nd }}$ & Pre-school & Upper intermediate (B2) \\
Fernando & $\mathrm{M}$ & 19 & Nursing & $2^{\text {nd }}$ & Secondary & Elementary (A2) \\
Hilda & $\mathrm{F}$ & 21 & Languages & $4^{\text {th }}$ & Secondary & Advanced (C1) \\
Irene & $\mathrm{F}$ & 19 & Business Admin & $2^{\text {nd }}$ & Primary & Intermediate (B1) \\
Jonathan & $\mathrm{M}$ & 19 & Public Relations & $2^{\text {nd }}$ & Secondary & Elementary (A2) \\
José & $\mathrm{M}$ & 21 & Computing & $4^{\text {th }}$ & Primary & Intermediate (B1) \\
Linda & $\mathrm{F}$ & 19 & Art & $1^{\text {st }}$ & Primary & Upper intermediate (B2) \\
Lupita & $\mathrm{F}$ & 21 & Languages & $4^{\text {th }}$ & Secondary & Advanced (C1) \\
Yasmin & $\mathrm{F}$ & 19 & Tourism & $2^{\text {nd }}$ & Primary & Elementary (A2) \\
\hline 3.2 Sequid & Methods & & & &
\end{tabular}

3.2 Sequence of Methods

The methodological approach used in this study was the 'life history' approach, a qualitative research tradition that allows the researcher to explore specific aspects of participants' past experiences and the way these experiences evolve over time (Goodson, Antikainen, Sikes, \& Andrews, 2017). Life history research was seen as ideal for the purposes of this study, as it would allow numerous examples of students' experiences to emerge, with reference to numerous different teachers per participant.

The specific methods utilised in this study were two extended life history interviews and a timeline activity. In the first interview, students were asked to discuss, in rather general terms, their experiences of learning English. The interviews lasted between 20 and 35 minutes, and were conducted in Spanish so that language would not be a barrier to students expressing themselves. The interviews were semi-structured in the sense that they tended to follow a chronological structure, but there were also opportunities to explore certain aspects in more detail. As mentioned previously, a key contribution of this study is its genuinely inductive nature. Because of this, it was important not to ask too many specific questions, and to only mention specific aspects after the students had introduced them.

At the end of each interview, the participants were given the instructions for the 'timeline' activity. This activity was an extension of the first interview, and involved participants summarising their language learning experiences in a visual form. As highlighted by an increasing number of studies outside of education (Adriansen, 2012; Kolar, Ahmad, Chan, \& Erickson, 2015; Sheridan, Chamberlain, \& Dupuis, 2011), timelines may enhance life history studies by helping participants recall, organise and express their ideas. The students were allowed a great deal of flexibility when creating their timelines, but they were also provided with some general guidelines to help them get started. These suggested that they began with a black line in the middle and included the 'significant events' in their life history on the line. They were recommended to write positive and negative experiences in different colours. The participants produced their timelines in unique and creative ways, and three examples have been provided in the Appendices.

After the students had completed their timelines, they were invited for a second interview in which they were 
able to explain what they had produced. This implied a certain degree of repetition between the first and second interviews; however, it allowed the researcher to cover some aspects in more detail and explore any doubts that had lingered from the first interviews. Given that there was a great deal of similarity between the first and second interviews, this increased confidence in the 'trustworthiness' of the findings (Lincoln \& Guba, 1985). The second interviews lasted between 10 and 30 minutes, and were also conducted in Spanish.

\subsection{Data Analysis}

In life history research, data analysis tends to be an ongoing, iterative process, and can often begin as soon as the first items of data are collected (Goodson \& Sikes, 2017). However, as the researcher was completing his work on the educational life histories of teachers, he did not analyse the data until approximately one year after data collection. This might be seen as a limitation of the study, but on a positive note, it gave him the opportunity to reflect upon his experiences analysing the teacher timelines (Bremner, 2017).

The interview data and timelines were transcribed, translated into English, and then analysed chronologically and thematically using NVivo. For the chronological coding, key time periods were created (for example, $1^{\text {st }}$ year of primary, $2^{\text {nd }}$ year of primary), and segments of data from all three sources were coded into the relevant time period. After each student case had been coded chronologically, a thematic analysis was carried out. Firstly, individual 'cases' were created for the 77 different teachers who had been mentioned by the participants. The researcher then read through each of them twice and created categories as they emerged. Clearly, completely inductive coding was not realistic, as the researcher was bound to have some pre-conceived notions in his mind. However, wherever possible, an effort was made to 'let the data speak for itself'. After an initial round of thematic analysis, the findings were condensed into three main categories, which were similar to those typically found in the literature: 'language knowledge and proficiency', 'teaching approach', and 'teacher-student roles and relationships'. These categories were then used to structure the cross-case analysis of the findings.

\subsection{Limitations of the Study}

Certain limitations of the study must be recognised. Firstly, the sample size of the study was relatively small, and it is important to emphasise that findings may not be generalised across contexts. However, as in life history research in general, the aim of the study was not to generalise across all contexts, but to suggest themes that may be transferable to different contexts (Lincoln \& Guba, 1985).

The second limitation was the inherent subjectivity in life history research. Participants may not have told the truth for various reasons, and they may also have forgotten certain events in their past (Brinkmann, 2019; Sikes \& Goodson, 2017). To a certain extent these limitations are an inevitable component of heavily qualitative approaches like life history; however, certain steps were taken in order reduce their impact on the trustworthiness of the study. For example, as an external visitor to the university, the researcher was not in a position of power over the students, which reduced the chances of them not wanting to express themselves honestly. Moreover, multiple opportunities for data collection (two interviews plus a timeline activity) increased the chances of trustworthy findings, as the timelines and second interviews were able to confirm what participants had said in the first interviews. Finally, the written timeline activity may have mitigated some of the issues of memory, as timelines have been suggested as important ways of enhancing recall (Van der Vaart, 2004).

\section{Findings}

This section has been divided into two parts. In the first part, an example of one student's educational life history is presented. This example is not necessarily representative of the other twelve cases, but has been included so that the reader can 'feel' the lived experience of one of the participants. In the second section, a cross-case analysis of the main themes emerging across the 13 cases has been provided. In both sections, numerous direct quotations have been included, in order to make it clear that the claims are grounded in the data.

\subsection{The Educational Life History of Irene}

This section presents a summarised version of the educational life history of Irene. At the time of data collection, Irene was starting her $2^{\text {nd }}$ year of a degree in Business Administration at the University of San Martín. Her timeline is one of the three timelines included in the Appendices.

Despite being exposed to English from an early age, Irene did not formally study the language until her $3^{\text {rd }}$ year of primary school. Her first experiences of English classes were positive, and she particularly appreciated the personalised attention that she received:

Irene: The teachers explained well and taught well. [...] The teachers were nice and patient; any question that you had they would answer nicely; they wouldn't continue until you fully understood a topic. For me 
that was a good teaching approach.

Unfortunately, due to family problems, Irene had to change schools for the last two years of primary school. At her new school, her experiences of English learning were more negative. It was especially frustrating for her as she had to repeat content that she had already studied:

Irene: We were in $5^{\text {th }}$ and $6^{\text {th }}$ grade and we were looking at things that I had done in $3^{\text {rd }}$ grade. [...] I already knew what we were looking at, so I didn't learn anything new.

Irene also felt that the teachers in this school took their role less seriously:

Irene: The teachers weren't interested; I don't think they had a real passion for teaching, because they would just make us answer exercises from the book. It was more like a day-care than teaching.

When it came to secondary school, Irene again went through a rather stressful experience of moving schools, but this time to the capital, Mexico City. However, she found learning at her new school to be much more positive:

Irene: There I liked the way they taught. [...] The teacher would bring in pictures, and she would make us create conversations or situations where we would use what she was teaching.

Irene also attended extra-curricular classes with teaching assistants, which she found useful:

Irene: Every two months teaching assistants would come in from other countries like the United States; actually one came from England. [...] So we also learnt different accents and different ways of pronouncing things, and they would speak about their culture, and for me this was new and interesting.

Unfortunately, Irene had to move yet again back to her home town for the $2^{\text {nd }}$ and $3^{\text {rd }}$ year of secondary school, where she had one of her worst experiences of learning English:

Irene: My teacher was about 60 years old, and her methods were outdated. She would arrive, teach her class, and that was it; maybe a few bits of homework from the book, it was just the book, just explaining and that was it.

Frustratingly, Irene again repeated the same content that she had studied in primary school:

Irene: There it was the same as I'd seen in primary school; we didn't do anything different from the verb 'to be' and things like that.

On top of that, Irene recalled that her teacher did not create the most positive atmosphere in class:

Irene: The teacher was really nagging, strict, and distant. She didn't even learn the names of the students, so it makes you feel that you're not important. If I'm not important to you, why should the class be important to me?

Things did not get much better for Irene when she started high school, which she felt was just as traditional as secondary school:

Irene: The first and second years of English were really repetitive; it was the same as what we'd done in secondary school. [...] I didn't show any interest in the class because it was just so repetitive, so I just thought 'what's the point?'

Fortunately, learning became slightly more meaningful in her final year of high school, where the teacher was much more enthusiastic:

Irene: I liked the teacher, she was fun, she was honest, [...] she was enthusiastic, she would say 'right guys, today I've got this activity or this movie for you to watch', you could see her energy, it made you want to learn, to go into her class.

Another important characteristic of Irene's final year at high school was that she learnt more technical language, which she found appealing:

Irene: We started to see technical vocabulary, English for tourism and things like that. [...] We were looking at something that I was interested in, in a language that I was interested in.

Irene then entered university to study Business Administration. As in her final year of high school, the English that was taught was now English for Specific Purposes, which Irene appreciated:

Irene: We've done presentations about prices of hotels and flights and things like that, I thought I wasn't going to like that, but it's been fun and interesting.

However, she did not have the best experiences with her first teacher at university: 
Irene: I think that she was missing the pedagogical side, to know how to make the student understand, how to capture their attention. [...] First of all she would speak more in Spanish, and if you spoke in Spanish it was fine, she didn't correct you. [...] She also missed a lot of classes, and I felt she was very distant.

Fortunately, her relationship improved with her most recent teacher. She particularly identified that she felt that the teacher cared about her and valued her opinion:

Irene: One thing that I really like about her is that she gives situations, for example she gives us a reading about a hotel in English and then she says 'this happened to me in a hotel' [...] and then she asks us 'has anything like that happened to you?'So you also speak, you might give your own points of view, so it's like she takes you into account, you feel part of the class.

When reflecting upon all her language learning experiences so far, Irene stated the following:

Researcher: So with all of your experience, what do you think are the best ways to learn a language?

Irene: I think visually, even if it sounds stupid, with pictures, drawings, examples, movies, situations. For example right now that we are studying English related to our degree [...] a real task, like a situation, a problem that you have to resolve in English. [...] And for example talking about motivation, the classes need to be dynamic, because if you go in and just teach theory it's going to be boring; you have to prepare activities to involve the students.

Finally, when asked to summarise what she thought was an optimal teacher-student relationship, she stated:

Irene: A relationship in which they care about you, involve you, not only teaching theory but also giving dynamic classes with activities, games, new techniques, conversations. [...] If the teacher is entertaining, has interesting things to talk about, has charisma and all of that, it motivates you.

This section has provided a brief taster of the educational life history of one of the students. In the next part, common themes are analysed from the life histories of all 13 participants.

\subsection{Cross-Case Analysis}

Table 2 summarises the common themes emerging from the data, along with the number of students mentioning them and the total number of teachers referenced.

Table 2. Summary table of themes emerging from the cross-case analysis

\begin{tabular}{|c|c|c|}
\hline Characteristic & $\begin{array}{l}\text { Mentioned by } \\
\text { (no. of students) }\end{array}$ & $\begin{array}{l}\text { With reference to } \\
\text { (no. of teachers) }\end{array}$ \\
\hline \multicolumn{3}{|l|}{ LANGUAGE KNOWLEDGE AND PROFICIENCY } \\
\hline Language knowledge/proficiency (viewed positively) & $2(15 \%)$ & $2(3 \%)$ \\
\hline Lack of language knowledge/proficiency & $6(46 \%)$ & $8(10 \%)$ \\
\hline \multicolumn{3}{|l|}{ TEACHING APPROACH } \\
\hline $\begin{array}{l}\text { Engaging, active, focus on real-life skills, immersion } \\
\text { (general characteristics of 'modern' language teaching) }\end{array}$ & $13(100 \%)$ & $35(45 \%)$ \\
\hline Engaging (appealing, interesting, fun) & $11(85 \%)$ & $16(21 \%)$ \\
\hline Active participation & $12(92 \%)$ & $29(38 \%)$ \\
\hline Focus on real-life skills & $10(77 \%)$ & $12(16 \%)$ \\
\hline Immersion in the target language & $6(46 \%)$ & $11(14 \%)$ \\
\hline $\begin{array}{l}\text { Boring, passive, overly theoretical, lack of immersion (general } \\
\text { characteristics of 'conservative' language teaching) }\end{array}$ & $13(100 \%)$ & $32(42 \%)$ \\
\hline Repeating the same content over and over & $4(31 \%)$ & $7(9 \%)$ \\
\hline Excessive focus on exams & $2(15 \%)$ & $4(5 \%)$ \\
\hline Lack of immersion in the target language & $4(31 \%)$ & $7(9 \%)$ \\
\hline \multicolumn{3}{|l|}{ TEACHER-STUDENT ROLES AND RELATIONSHIPS } \\
\hline Positive teacher-student relationship & $13(100 \%)$ & $32(42 \%)$ \\
\hline Teachers care about students; personalised attention & $13(100 \%)$ & $19(25 \%)$ \\
\hline Negative teacher-student relationship & $13(100 \%)$ & $31(40 \%)$ \\
\hline $\begin{array}{l}\text { Teachers not seeming to care about students; lack of personalised } \\
\text { attention }\end{array}$ & $10(77 \%)$ & $24(31 \%)$ \\
\hline
\end{tabular}


As mentioned in the Methods section, three main categories emerged from the data: 'language knowledge and proficiency', 'teaching approach', and 'teacher-student roles and relationships'. These areas are discussed separately in the following three sub-sections.

\subsubsection{Language Knowledge and Proficiency}

'Language knowledge and proficiency'; that is to say, teachers' knowledge about and ability to use the English language, was only mentioned as a positive characteristic by 2 out the 13 students:

Beatriz: I think I have a very good English teacher because she knows a lot. (Teacher 17)

Irene: She really did know English and she knew how to explain the reason for things; if you asked her 'why does this word come here?' she knew the answer. (Teacher 45)

However, a lack of language knowledge and/or proficiency was mentioned more regularly, with 6 out of the 13 students mentioning it, for example:

Jonathan: I had a problem with the teacher, because she didn't speak English very well. [...] She would give us dictations, and that's where it was frustrating, because of her pronunciation, it wasn't bad but it wasn't good enough. (Teacher 52)

Beatriz: Sometimes the teacher didn't pronounce certain words very well and I tried to correct her and she got angry with me. [...] It was really frustrating. (Teacher 11)

The fact that 'language knowledge and proficiency' was rarely mentioned as a positive characteristic, but was fairly common as a negative characteristic, suggests that it was seen by the students as a basic skill needed by all English teachers: rarely appreciated, but noticed when missing.

\subsubsection{Teaching Approach}

The students made considerably more references to 'teaching approach' than 'language knowledge and proficiency'. One of the most commonly mentioned characteristics was making learning engaging ('engaging' in the sense of being appealing, interesting, fun), which was mentioned by 11 out of the 13 participants:

Dolores: We had a teacher who I really liked. She was really nice and she had lots of different strategies to make the class interesting. [...] Learning was fun, it was like a game and I enjoyed it. [...] At the beginning of the class she would show us some flash cards; there were stories; every day was different. (Teacher 23)

José: He isn't the typical formal teacher who comes in to teach the same thing [...] there are always new things; he includes games, multimedia, lots of things to capture your attention and to keep you interested. (Teacher 15)

Being encouraged to actively participate in class was mentioned by 12 out of the 13 students. Here, the Spanish words dinámico/dinámica (literally 'dynamic') were often used to describe a more active style of learning:

Anabel: I had a teacher who made the classes really dynamic. [...] I paid attention, participated, and answered questions. (Teacher 2)

Beatriz: I had a really good English teacher. She was really dynamic. [...] What I liked was that we would practise; we would do lots of dialogues, so it would encourage us to speak and develop more. [...] She made you want to go to her class, you wanted for it to be time for English. (Teacher 12)

Students' active involvement in class tended to imply a movement away from overly theoretical and grammar-based approaches towards more practical, skills-based approaches:

José: He makes you apply what you're doing practically. He tells you 'what you're really going to use is this'. (Teacher 15)

Camila: The teacher made the classes practical; if she was going to teach us the vocabulary of clothing, she would let us dress up and learn the names of clothes in English. And then for example we looked at restaurants and he gave us a role-play of a restaurant. (Teacher 18)

Especially at later stages of their educational life histories, the students seemed to appreciate being able to practise the vocabulary in more meaningful contexts:

Linda: She doesn't explain basic things like structures or grammar. [...] We've been taught technical vocabulary, and that's was what I've found interesting more than anything else. (Teacher 9)

Immersion in the target language (i.e. speaking in English most or all of the time) was also highlighted as an important characteristic by 6 out of the 13 students, for example: 
Dolores: We had a teacher from Nigeria, and with him everything was in English. [...] The fact that he was speaking in English all the time helped a lot, I mean there were some things that we didn't understand but then learning English became more of a necessity. (Teacher 28)

Linda: She made me speak in English all the time [...] and I think that was to start training my ear, and to take away a bit of the fear of speaking another language. (Teacher 62)

In total, the students highlighted positive characteristics related to 'teaching approach' in relation to 35 out of the 77 teachers mentioned in the study. However, the students also made reference to another 32 teachers who they perceived to be ineffective. These teachers were essentially the opposite of those considered positive: that is to say, they were unengaging, passive and overly theoretical:

Jonathan: When I started, learning a language was a new experience, so it was cool. But when I had the other teacher I realised that it wasn't as good as I thought. [...] It was like we were studying Maths, [...] it was just writing, writing, writing, and learning formulas. (Teacher 50)

Yasmin: We were like parrots, we would just learn what words sounded like and say them, but there wasn't really a product that came from it, or learning, nothing. (Teacher 74)

Alfonso: They taught us the verb 'to be' and all that, the basic stuff; it was a very traditional and outdated style of teaching. [...] It was like how I imagine they used to teach in the eighties.

Researcher: Was it like the audiovisual method? Like 'listen and repeat, listen and repeat'?

Alfonso: Actually it was more just like 'listen'. (Teacher 8)

One of the key negative characteristics was a lack of immersion in the target language:

Hilda: The teacher didn't speak to us in the language that we were supposed to be learning. [...] If you asked him to speak in English he would say one or two phrases and then go back to Spanish. (Teacher 41)

Another frustration was having to repeat the same content over and over:

Alfonso: In secondary school I had three teachers, each year it was a different teacher, but they were all the same, they all repeated the same things. (Teacher 8)

Furthermore, two students highlighted their frustration at classes which were solely focused on the exam:

Dolores: [In secondary school] we were prepared to get English certificates [...] [In $2^{\text {nd }}$ semester of high school] it was the same, preparing for the exam. [...] And in the last year [of university], it was just pure TOEFL, all the time, so it was super boring. (Teachers 26, 31 and 32)

It must be acknowledged that there was not total agreement regarding all of the previous points. For example, in the case of immersion in the language, Yasmin reported the rather traumatic experience of being immersed in English in her first year at a bilingual primary school:

Yasmin: I remember that it was really, really bad for me. [...] I didn't know what the teacher was saying at all, so those classes were wasted on me. [...] They might as well have been speaking in Chinese. [...] I felt tiny; it was like 'how can I be the only one who doesn't understand?' (Teacher 72)

It should also be recognised that not all students gave a completely negative response to traditional teaching in general. For example, Anabel, whilst generally preferring a more active approach, also saw the value of a more grammar-based approach:

Anabel: [In $2^{\text {nd }}$ semester of high school] it was back to traditional classes again, but I felt I learnt anyway. (Teacher 3)

Other students expressed similar views about the importance of grammar:

Researcher: Does [Teacher 17] still do some traditional things, or has she moved away from that?

Jonathan: Yes, a little, the classic worksheets from a textbook with exercises for us to do. It's 'traditional', but it's vital, it has to be that way. (Teacher 17)

José: I mean she did follow the pattern of explaining the basics, the same old stuff, but it was a good job she did, I mean, they are the foundations. (Teacher 58)

The quotations above indicate that there is clearly still a place for more 'conservative' approaches in effective language teaching. However, the overwhelming message from the students was that a completely 'conservative' approach was not seen as effective as more 'modern' approaches. 


\subsubsection{Teacher-Student Roles and Relationships}

The findings show that the students felt that a more engaging, active, meaningful approach was a key characteristic of effective teaching. However, they placed just as much emphasis on teacher-student roles and relationships. Indeed, a positive teacher-student relationship, together with fostering a comfortable learning environment, were mentioned by all 13 students, with 32 different examples of positive teachers. Some examples included:

Beatriz: I had one of those teachers who inspires you to come to class, who you feel that trust with. With her I started to feel comfortable to be able to develop my English. (Teacher 16)

Fernando: I felt really, really comfortable because you could speak to her in and out of the classes. [...] It wasn't like 'I'm your teacher and you have to respect me in and out of class'; we did respect her but you could also have a joke and talk about other things. (Teacher 14)

Hilda: I feel really happy now because the teacher makes us feel comfortable enough to speak in class [...] She's never above us, she comes down to our level so that we feel more comfortable to ask questions and participate. (Teacher 71)

Conversely, there were also several examples of negative teacher-student relationships:

Hilda: At one point I didn't want to continue studying my degree because the teacher was really demanding and sometimes the way he taught was demotivating. [...] It inhibited us because he would stare at us as if he was going to kill us or something. [...] He wouldn't take his eyes of you, and you would feel that stare, it made you feel tiny. (Teacher 70)

Dolores: I had another teacher who I didn't like. [...] She was bossy, she wasn't understanding with us at all, she would tell us off and she didn't care how we felt. (Teacher 25)

The previous quotation show how bad the students felt when they did not feel the teachers cared about them. In fact, a regularly mentioned characteristic of effective teachers was caring about students and being prepared to give them personalised attention:

Researcher: If you think back on all your experience of learning English, what do you think is the best characteristic?

Jonathan: That [the teacher] cares about us. [...] That she cares about our learning. [...] When we presented and did our own activities, she would do them too, so it was like 'she really is paying attention to us'. (Teacher 17)

Hilda: She really tries to make the students learn, to understand what we're looking at. With her, if we're doing an activity, she comes up to us and asks us if we understood. [...] If you make a mistake she corrects you and you can keep talking, and you can ask her any question you want and she'll respond. (Teacher 71)

In contrast to this, there were numerous examples of teachers not appearing to care. One of the most common phrases here was teachers 'just teaching the class', without worrying about the students and their learning:

Jonathan: I felt that she didn't care if we learnt or not, she was just there to teach her class and that was it. (Teacher 55)

Dolores: The teacher just taught the class. There wasn't much interest from the teacher towards the students and not much of a relationship between the teacher and the students. (Teacher 26)

Fernando: There wasn't much communication with the teacher, he would have his back to us as he wrote on the board or he would be dictating something; he would rarely turn round and look at you because he was doing his own thing. [...] He was the typical English teacher who would just turn up, tell you things and then leave. (Teacher 36)

The overwhelming message was that a positive relationship with the students, and providing them with personalised attention, were considered key characteristics of effective teaching. Indeed, on the whole, the students preferred the teacher to 'be there' to help where possible, and to resolve their doubts there and then. In fact, learner autonomy was only explicitly mentioned as a positive characteristic by 3 out of the 13 students. One student who did express a positive inclination towards learner autonomy was Camila:

Camila: We are autonomous and I agree with the way of teaching. [...] He gives us lots of projects and homework at the same time, but you have the freedom to choose when you're going to do each project and which one you're going to first, so I think it's good that he gives us that trust and freedom. (Teacher 22) 
In contrast, Fernando expressed strong views against too much learner autonomy, with reference to the same teacher:

Fernando: I think that in $1^{\text {st }}$ semester it was really interactive and well-explained. [...] The classes were clear, and so much homework wasn't necessary, because what we had learnt had stuck in our heads. [...] But in $2^{\text {nd }}$ semester that's all been thrown away, and we've been completely left by ourselves to be independent. [...]

Researcher: So you'd like the teacher to be closer, to respond to your questions?

Fernando: Exactly, which he doesn't do. [...] It's like he's ignoring us, and I don't like that. [...] It is good for us to be independent, but they should be introducing it to us little by little, not so directly. (Teacher 22)

Even Camila, who did appreciate her new autonomous role, recognised that she would like more teacher intervention. Like Fernando, she suggested that the transition to increased student autonomy should be made more gradually:

Camila: Sometimes it's too much freedom, because we take advantage. [...] On one hand it's a good thing, because [Teacher 22] is right, we don't need anyone to be telling us over and over again to do homework, it's our responsibility. But on the other hand, we come from a system in which we're used to people reminding us.

This more gradual transition seems more important given that students like Camila, despite learning English for over a decade, still do not feel they have the 'basics' of English:

Camila: I feel that because the teacher gives us so many projects, there's so much to do but so little time, so we can't really make anything out of it. [...]

Researcher: So you would like to do fewer activities but in more depth?

Camila: Yes. Sometimes he leaves us a piece of work and he says 'this is basic stuff', because we should have already seen it in secondary school and high school. But these same doubts are still there, what I didn't understand in secondary school I didn't understand in high school and I still don't understand at university. [...] Maybe if we had the basics of English, something concrete to fall back on, we would be able to take on that autonomous role. But as we don't really have anything solid, when we want to be autonomous we get lost, we don't know where to start. I think that they should make sure we learn first, I mean really learn, and then let us off on our own.

\section{Discussion}

The educational life histories of the 13 students highlighted a range of positive and negative experiences of English language teaching in Mexico. Around half of the teachers mentioned by students were seen as ineffective, with some rather stark examples of poor language teaching. These negative experiences, especially the more extreme examples, paint a rather depressing picture of English language learning in Mexico, as has been highlighted by authors such as Davies (2009). However, it must also be recognised that around half of the teachers mentioned were seen in a positive light, and almost all participants identified at least one particularly effective teacher.

What can be learnt from the students' positive experiences? Firstly, that students do not seem to value language knowledge and proficiency - unless it is not there. These findings are similar to those found in the qualitative study of Barnes and Lock (2010), in which relatively few participants included language knowledge and proficiency in their written statement of an effective language teacher. Given that this characteristic is consistently considered to be important in studies utilising deductive methods, it would appear that this is not thought to be the essence of an effective teacher, but is nevertheless expected as a sort of 'basic requirement' of a language teacher.

Secondly, on the whole, the students preferred teachers who made learning engaging, active and meaningful, and did not like teaching that was unappealing, passive, overly theoretical with too much use of the L1. These findings generally support those found in the literature (Alimorad \& Tajgozari, 2016; Barnes \& Lock, 2010; Kourieos \& Evripidou, 2013; Oskouei et al., 2018; Richter \& Lara Herrera, 2017). Indeed, although certain participants made reference to needing more 'conservative' approaches at times (as in Brown, 2009), the overwhelming tendency was towards more 'modern' approaches.

Equally as important as 'teaching approach' were 'teacher-student roles and relationships'. The students placed significant emphasis on the human element; they valued a positive teacher-student relationship in which they felt comfortable, and greatly appreciated teachers who they perceived to care about them and their learning. Again, 
these findings are consistent with other case studies in the literature (Barnes \& Lock, 2010; Brosh, 1996; Chen, Y-J, Lin, 2009; Han, 2017; Richter \& Lara Herrera, 2017).

Perhaps the most interesting finding was the general lack of interest the Mexican students had in autonomous learning. Autonomous learning is often seen as an integral part of more 'modern', student-centred approaches (Jones, 2007; Nunan, 2013), but most students did not value teachers expecting them to be autonomous - they wanted teachers to be there for them and to help them with their problems in class. Further studies might be able to illuminate how typical such attitudes are; perhaps this has to do with this particular sample of students, relatively low levels of English, and/or the values typically associated with the Mexican educational culture. However, the findings serve as a reminder for teachers not to reach absolute conclusions about teaching effectiveness. Indeed, although the clear message of this study was that students favoured more 'modern' approaches, many still valued some characteristics of more 'conservative', teacher-centred learning. As has been emphasised previously (Bremner, 2019; Brinkmann, 2019), a more pragmatic attitude is more likely to be successful than 'all-or-nothing' approaches.

\section{Implications}

This study took place with a small sample of students in a particular Mexican university context, and the findings are clearly not generalisable to all contexts. However, readers from contexts with similar characteristics may be able to judge the extent to which the findings are transferable to their own settings, as many contexts will share similarities with the context of this study. Moreover, although there will inevitably be differences in perceptions of effective language teaching in different contexts, several key similarities have now emerged over a range of case studies from different countries (notably the tendency towards more 'modern' approaches and the importance of positive teacher-student relationships). In light of this growing consensus, it is important that these student views are taken into account, and acted upon, by teachers and educational decision-makers.

Of course, listening to students' perspectives does not mean doing everything students say. Students do not always 'know what's best for them', teachers have valuable training and experience to guide their decision-making, and, in any case, it is not always possible to adopt certain strategies due to contextual constraints (Bremner, 2015; Phipps \& Borg, 2009; Ramírez Romero \& Pamplón Irigoyen, 2012). However, as suggested by authors such as Brown (2009) and Barnes and Lock (2010), being aware of what students think will surely better place teachers to make informed decisions about their teaching. If potential mismatches between teacher and students' perspectives are identified, this might mean making adaptations to teaching. However, it might also simply mean having a short dialogue with students to discuss what might be possible in a given context.

Gathering data from students does not have to be through formal research or academic mechanisms, and can take place through more localised and informal means. For example, given that the participants in this study generally found the timeline activity to be useful in terms of reflecting on their learning, perhaps teachers could organise similar tasks with their own students, either individually or in groups. This would be an excellent way both for students to take stock of their own learning and for teachers to gather valuable information about what their students think is effective teaching.

A final implication of the study is the importance of qualitative and inductive methods. Indeed, whilst quantitative surveys might obtain results from large samples of students, they are susceptible to missing what students really want to say, and may even 'lead' students towards pre-established responses. Conversely, qualitative inductive approaches, and especially those focusing on real, concrete experiences such as those articulated in this study, bring us closer to the real lived experiences and the characteristics of teaching that leave long-lasting effects on students. If teachers and educational decision-makers are serious about listening to what students think, we have to give them the freedom to express themselves in their own words, not just in ours. This is the fundamental principle of the 'emic' perspective, and is one of the key components of a more 'student-centred' approach to education.

\section{References}

Adriansen, H. K. (2012). Timeline interviews: A tool for conducting life history research. Qualitative Studies, 3(1), 40-55. https://doi.org/10.7146/qs.v3i1.6272

Al-Mahrooqi, R., Denman, C., Al-Siyabi, J., \& Al-Maamari, F. (2015). Characteristics of a good EFL teacher: Omani EFL teacher and student perspectives. SAGE Open. https://doi.org/10.1177/2158244015584782

Alimorad, Z., \& Tajgozari, M. (2016). A comparison of Iranian high school teachers' and students' perceptions of effective English teachers. SAGE Open. https://doi.org/10.1177/2158244016679212 
Arikan, A., Taşer, D., \& Saraç-Süser, H. S. (2008). The effective English language teacher from the perspectives of Turkish preparatory school students. Education and Science, 33(150), 42-51. Retrieved from https://files.eric.ed.gov/fulltext/ED506217.pdf

Babai Shishavan, H., \& Sadeghi, K. (2009). Characteristics of an effective English language teacher as perceived by Iranian teachers and learners of English. English Language Teaching, 2(4), 130-143. Retrieved from https://pdfs.semanticscholar.org/4100/f30d631dcb3c3859497c154fe2ff9cb54445.pdf

Barnes, B. D., \& Lock, G. (2010). The attributes of effective lecturers of English as a Foreign Language as perceived by students in a Korean university. Australian Journal of Teacher Education, 35(1), 139-152. https://doi.org/10.14221/ajte.2010v35n1.2

Barnes, B. D., \& Lock, G. (2013). Student perceptions of effective foreign language teachers: A quantitative investigation from a Korean university. Australian Journal of Teacher Education, 38(2), 19-36. https://doi.org/10.14221/ajte.2013v38n2.2

Borg, S. (2006). Teacher cognition and language education: Research and practice. London: Continuum.

Bremner, N. (2015). Reculturing teachers as just the tip of the iceberg: Ongoing challenges for the implementation of student-centred EFL learning in Mexico. MEXTESOL Journal, 39(3), 1-14. Retrieved from http://www.mextesol.net/journal/index.php?page=journal\&id_article $=752$

Bremner, N. (2019). From learner-centred to learning-centred: Becoming a "hybrid" practitioner. International Journal of Educational Research, 97, 53-64. https://doi.org/10.1016/j.ijer.2019.06.012

Brinkmann, S. (2019). Teachers' beliefs and educational reform in India: From "learner-centred" to “learning-centred." Comparative Education, 55(1), 9-29. https://doi.org/10.1080/03050068.2018.1541661

Brosh, H. (1996). Perceived characteristics of the effective language teacher. Foreign Language Annals, 29(2), 125-136. https://doi.org/10.1111/j.1944-9720.1996.tb02322.x

Brown, A. V. (2009). Students' and teachers' perceptions of effective foreign language teaching: A comparison of ideals. The Modern Language Journal, 93. https://doi.org/10.1111/j.1540-4781.2009.00827.x

Çelik, S., Arikan, A., \& Caner, M. (2013). In the eyes of Turkish EFL learners: What makes an effective foreign language teacher? Portal Linguarum, 20, 287-297. Retrieved from https://files.eric.ed.gov/fulltext/ED549671.pdf

Chen, Y-J, Lin, S.-C. (2009). Exploring characteristics for effective EFL teachers from the perceptions of junior high school students in Tainan. STUT Journal of Humanities and Social Sciences, 2, 219-249. Retrieved from https://society.stust.edu.tw/Sysid/society_en/files/Vol. 2/7. Exploring Characteristics for Effective EFL Teachers From the Perceptions of Junior High School Students in Tainan.pdf

Davies, P. (2009). Strategic management of ELT in public educational systems: Trying to reduce failure, increase $\begin{array}{lllll}\text { success. } & T E S L-E J, & 13(3), & \text { Retrieved } & \text { from }\end{array}$ http://www.tesl-ej.org/wordpress/issues/volume13/ej51/ej51a2/

Faranda, W. T., \& Clarke, I. (2004). Student observations of outstanding teaching: Implications for marketing educators. Journal of Marketing Education, 26(3), 271-281. https://doi.org/10.1177/0273475304268782

Goodson, I., Antikainen, A., Sikes, P., \& Andrews, M. (Eds.). (2017). The Routledge International Handbook on Narrative and Life History. Abingdon, Oxon: Routledge.

Goodson, I., \& Sikes, P. (2017). Techniques for doing life history. In I. Goodson, A. Antikainen, P. Sikes, \& M. Andrews (Eds.), The Routledge International Handbook on Narrative and Life History (pp. 72-88). Abingdon, Oxon: Routledge.

Han, I. (2017). Attributes of quality English teachers and teaching perceived by academic high school students in Korea. Modern English Education, 18(4), 135-163. https://doi.org/10.18095/meeso.2017.18.4.07

Jones, L. (2007). The student-centred classroom. New York: Cambridge University Press.

Kolar, K., Ahmad, F., Chan, L., \& Erickson, P. G. (2015). Timeline mapping in qualitative interviews: A study of resilience with marginalized groups. International Journal of Qualitative Methods, 14, 13-32. https://doi.org/10.1177/160940691501400302

Kourieos, S., \& Evripidou, D. (2013). Students' perceptions of effective EFL teachers in university settings in Cyprus. English Language Teaching, 6(11), 1-16. https://doi.org/10.5539/elt.v6n11p1

Lincoln, Y. S., \& Guba, E. (1985). Naturalistic inquiry. Beverly Hills, CA: Sage. 
Meksophawannagul, M. (2015). Teacher and learner views on effective English teaching in the Thai context: The case of engineering students. English Language Teaching, 8(11), 99-116. https://doi.org/10.5539/elt.v8n11p99

Nunan, D. (2013). Learner-centered English language education: The selected works of David Nunan. New York: Routledge.

Oskouei, A. O., Dabaghi, A., \& Nejad Ansari, D. (2018). Exploring effective foreign language teaching from the eyes of Iranian learners: Reporting a qualitative interview study. The Qualitative Report, 23(10), 2453-2473. Retrieved from https://nsuworks.nova.edu/tqr/vol23/iss 10/12

Park, G.-P., \& Lee, H.-W. (2006). The characteristics of effective english teachers as perceived by high school teachers and students in Korea. Asia Pacific Education Review, 7(2), 236-248. https://doi.org/10.1007/BF03031547

Phipps, S., \& Borg, S. (2009). Exploring tensions between teachers' grammar teaching beliefs and practices. System, 37, 380-390. https://doi.org/10.1016/j.system.2009.03.002

Ramírez Romero, J. L., \& Pamplón Irigoyen, E. N. (2012). Research in English language teaching and learning in Mexico: Findings related to students, teachers and teaching methods. In R. Roux, A. Mora, \& P. Trejo (Eds.), Research in English Language Teaching: Mexican perspectives. Bloomington, IN: Palibrio.

Richter, K. G., \& Lara Herrera, R. (2017). Characteristics and pedagogical behaviours of good EFL instructors: The views of selected Southeast Asian and Mexican SLTE students. RELC Journal, 48(2), 180-196. https://doi.org/10.1177/0033688216645473

Schultz, R. A. (2001). Cultural differences in student and teacher perceptions concerning the role of grammar instruction and corrective feedback: USA-Colombia. Modern Language Journal, 85, 244-258. https://doi.org/10.1111/0026-7902.00107

Sheridan, J., Chamberlain, K., \& Dupuis, A. (2011). Timelining: Visualizing experience. Qualitative Research, 11, 552-569. https://doi.org/10.1177/1468794111413235

Sikes, P., \& Goodson, I. (2017). What have you got when you've got a life story? In I. Goodson, A. Antikainen, P. Sikes, \& M. Andrews (Eds.), The Routledge International Handbook on Narrative and Life History (pp. 60-71). Abingdon, Oxon: Routledge.

Van der Vaart, W. (2004). The time-line as a device to enhance recall in standardized research interviews: A split ballot study. Journal of Official Statistics, 20(2), 301-317. 


\section{Appendix A}

\section{Irene's timeline}

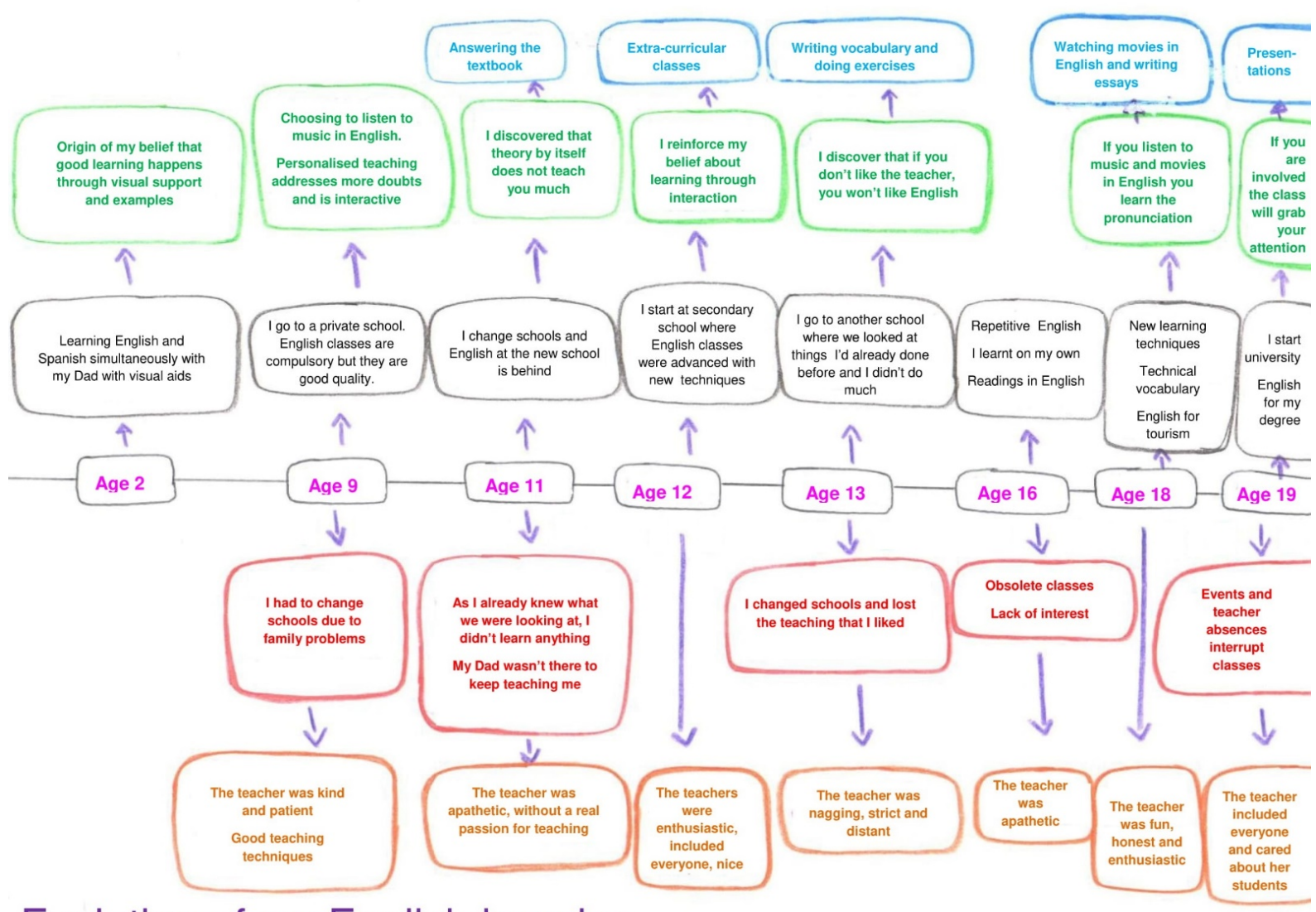

\section{Evolution of my English learning}




\section{Appendix B}

\section{Dolores's timeline}

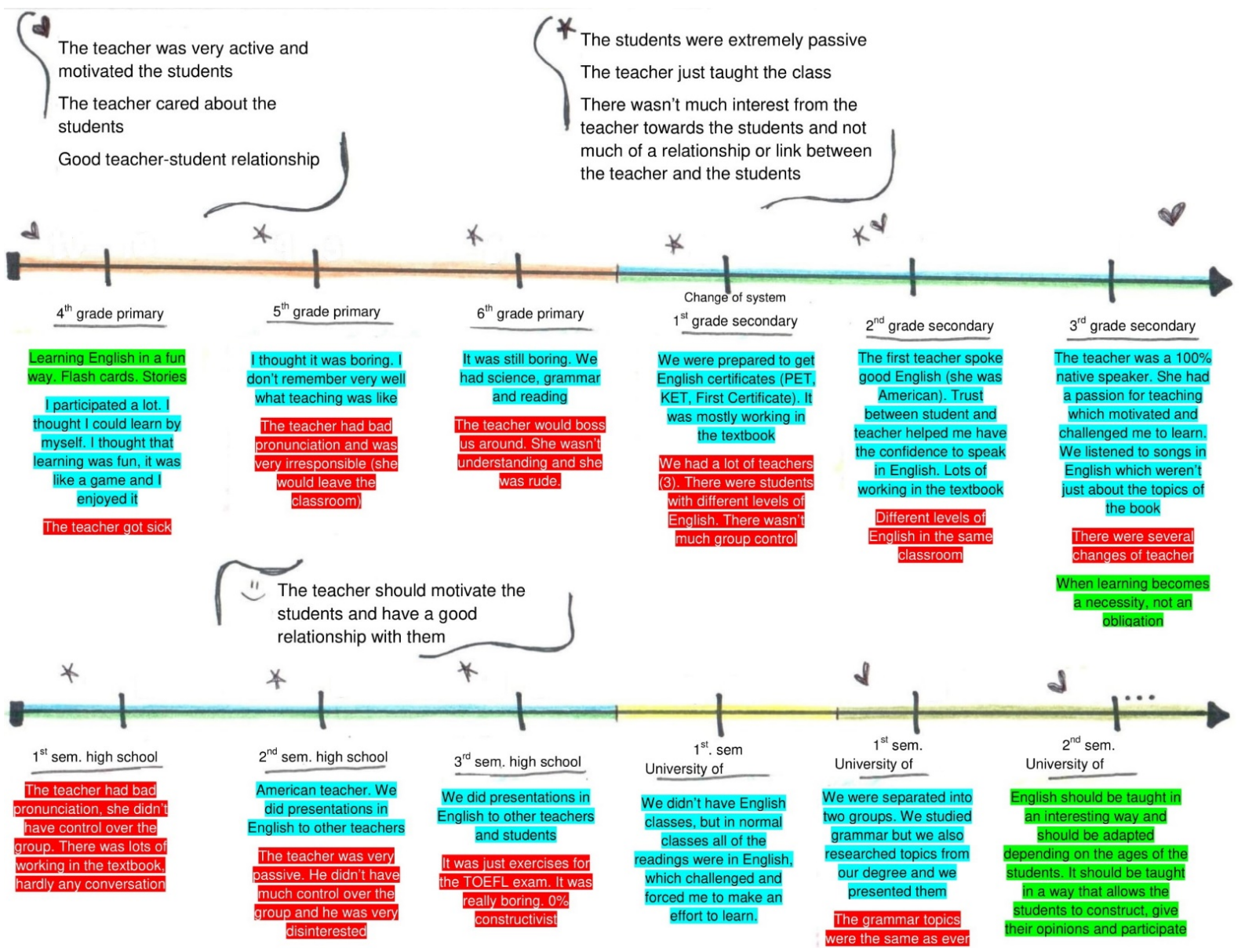




\section{Appendix C}

\section{Alfonso's timeline}

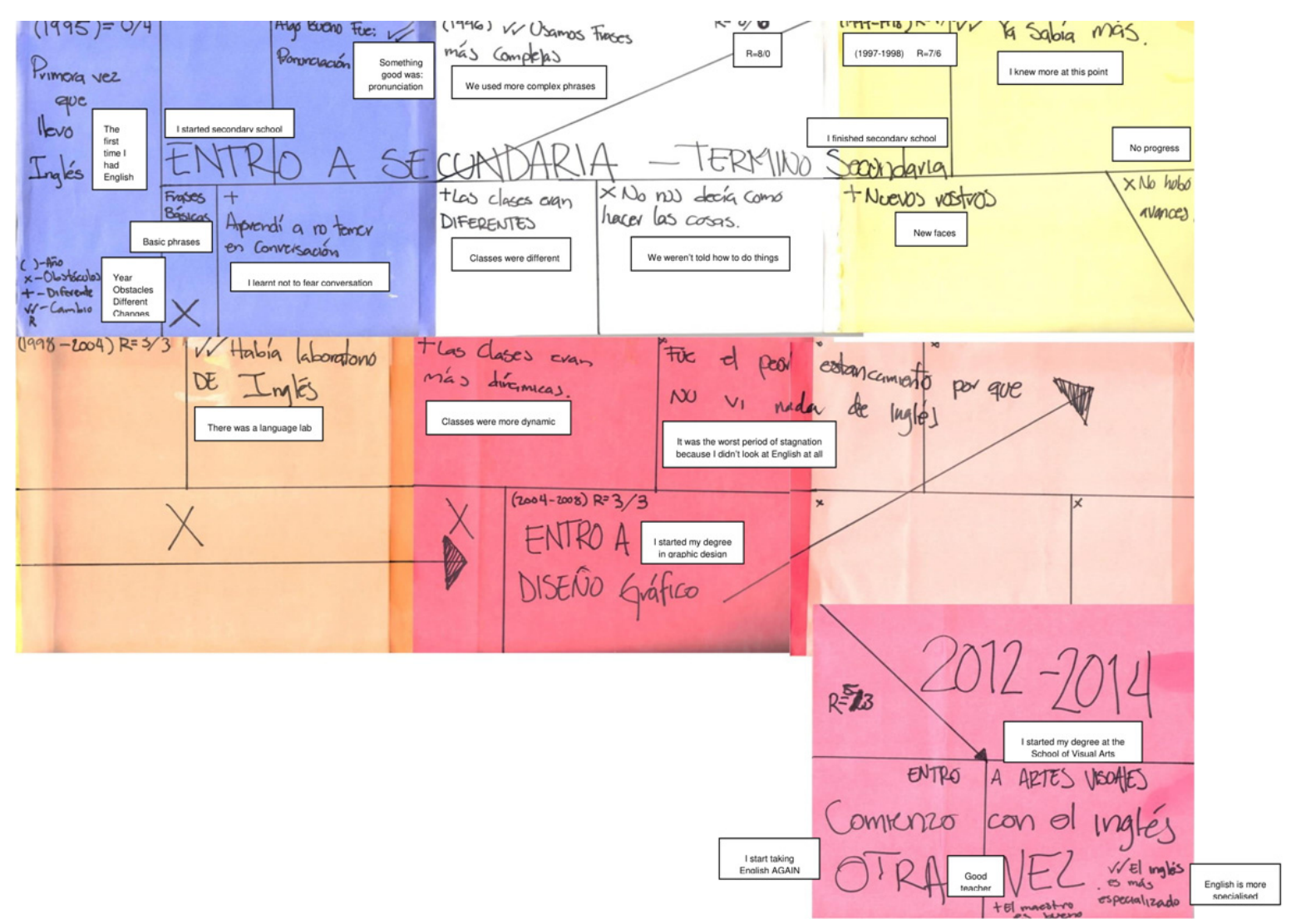

\section{Copyrights}

Copyright for this article is retained by the author(s), with first publication rights granted to the journal.

This is an open-access article distributed under the terms and conditions of the Creative Commons Attribution license (http://creativecommons.org/licenses/by/3.0/). 